\title{
Why New Zealand Doesn't Need a Written Constitution
}

\author{
James Allan
}

W

HEN lawyers and constitutional scholars talk of a 'written constitution' they use the term in a formal, technical sense. They mean a country's authoritative, and often founding, document or series of documents which contains that country's most important laws about its system of government. This uniquely prominent written document is referred to as 'the Constitution' and will normally have two characteristics. It will contain a country's fundamenta/ laws (say, about, and giving authority to, the principal organs of state), and these laws will be of a higher form and status than laws derived from sources other than the Constitution.

In the developed world, New Zealand is virtually unique in not having a written constitution. Only the United Kingdom and Israel, among all other civil societies, also lack such a pre-eminent constitutional document and so, too, can be described as lacking a written constitution in this formal sense.

Why, then, does New Zealand not have a written constitution? Broadly speaking there are three reasons. First, New Zealand's legal and constitutional heritage is English. New Zealand inherited the Westminster form of government and, as noted, the UK is one - the pre-eminent one - of those few countries without a written constitution. The Legislature Act 1908 transferred the privileges, immunities, and powers of the imperial parliament as of 1 January 1865 to the New Zealand parliament. The English Laws Act 1858 did basically the same with the existing body of English law. Earlier, Westminster's New Zealand Constitution Act 1852 had created a General Assembly for the colony of New Zealand to 'make laws for the Peace, Order, and Good Government of New Zealand' (s.53) and thereby had sown the seed of parliamentary sovereignty.

Of course, countries like Australia and Canada also inherited the Westminster system of government from England but did so with a written constitution (in the form of an Act of the imperial parliament) included. The difference in these cases, however, was one of size. Canada and Australia were so large that only a federal system of government was practical, and federal government requires a defining document setting out, as higher law, the division of powers between the central and state governments. This is the second reason for the absence in New Zealand of a

${ }^{1}$ See, for example, Joseph (1993:5-12).

James Allan is Senior Lecturer in Law at The University of Otago. 
written constitution: New Zealand, along with the UK (and Israel too for that matter), is a relatively small (in terms of area) unitary, not federal, state.

The third main reason for the absence of a written constitution in New Zealand is more ethereal. There has never been much dissatisfaction (at least among the preponderance of citizens) with the historical legacy. Accordingly, there has been little demand for a new start or refounding of the political structures. Had there been such a demand, a most likely concomitant effect would have been the adoption of a written constitution.

\section{Calls to Join the (Written) Club}

Nevertheless, New Zealand's current constitutional structure is not universally admired. In particular, two former Labour Prime Ministers have recently raised the possibility of New Zealand adopting a written constitution. One is Sir Geoffrey Palmer, who advocates a written constitution which would include and entrench both a justiciable Bill of Rights and the Treaty of Waitangi. ${ }^{2}$ Sir Geoffrey's vision can be traced back to the mid-1980s when, first as Minister of Justice and then as Prime Minister, he tried, and failed, to have an entrenched Bill of Rights adopted. ${ }^{3}$ But that vision has remained relatively amorphous; Sir Geoffrey has advanced no detailed proposals for moving from the present constitutional structure to his preferred arrangement.

Not so with former Prime Minister Mike Moore. Today a backbench opposition Labour MP, the Right Honourable Mike Moore has recently had drafted a private member's Bill which, were it ever to be enacted, could well lead to New Zealand adopting a written constitution. Moore's Constitutional Convention Bill seeks to establish a constitutional convention which would then consider, among other matters, whether:

- a draft written constitution for New Zealand should be drawn up;

- an entrenched Bill of Rights should be included;

- New Zealand should become a republic;

- the right of appeal to the Privy Council should be ended; and whether

- the new proportional-representation voting system adopted in 1993 should be maintained, altered or abolished.

The Bill provides in the first instance for the establishment of a so-called Leadership Council consisting of the elected leaders of all the parties in parliament. This

\footnotetext{
${ }^{2}$ See, for example, Geoffrey and Matthew Palmer (1997:311-16).

3

Instead a statutory Bill of Rights was enacted with a section specifying that this Bill of Rights was not to override any other statutes. For more on the New Zealand Bill of Rights Act 1990, see Allan (1997).
} 
Leadership Council would then appoint nine people of high standing in the community to a so-called Eminent Persons Group. The two bodies would cooperate in preparing for, and supervising the holding of, a Constitutional Convention. This convention would be peopled with 35 elected members (five from Maori electoral districts), $20 \mathrm{MPs}$ appointed by the Leadership Council, up to ten further appointees named by the Leadership Council after consulting with the Eminent Persons Group, and a few special delegates such as ex-Governors General and ex-Prime Minsters. Any and all proposals for change made by the Constitutional Convention would be put to, and to take effect have to be passed by, a popular referendum.

In many respects this Bill makes for very odd reading. The explanatory note with which it begins is part potted history of New Zealand, part outline of the Bill's provisions, and part a blend of personal commentary about New Zealand's past and implicit warnings about its future. Frequent references are made to the coming millennium, as though having a year with lots of zeros in it, or one that can be divided evenly by 1,000 , is a reason in itself for constitutional change. The reader is told in all apparent seriousness that "The Convention is required to endeavour to achieve a consensus on [these] matters' - an unlikely feat indeed unless consensus is interpreted merely as a majority view. The Treaty of Waitangi is simply asserted to have some special status and to be some sort of founding document of New Zealand, as though this were not a contentious claim. ${ }^{4}$ All in all the Moore Bill seems a thinly veiled effort to have New Zealand adopt a written constitution, together with as many other US-like constitutional attractions as possible. Nor would any New Zealander miss the irony of Mike Moore, the populist politician, drafting a Bill that leaves much power in the hands of eminent worthies and party leaders.

That said, this is a private member's Bill. As such it will need to win parliamentary time cven to be given a hearing. This is unlikely. Even should that happen, the present government, with its parliamentary majority, will ensure that the Bill is defeated. So in practical terms Moore's Bill, in my view, is at best a stalking horse for a possible route to change sometime in the indefinite future.

\section{Write it Down and Make the Judiciary Even More Powerful}

My own preference is for New Zealand to remain without a written constitution. The inevitable effect of adopting a written constitution, in my view, is an increase in judicial power. It will be the judges, after all, who will be given the ultimate power to interpret the words in any written constitution. In effect, the judges will make social policy and determine winners and losers in society depending upon the meanings those judges choose to give to the various provisions in the particular pre-eminent written document.

\footnotetext{
For a well argued book taking the view that the claim is false, see Kenneth Minogue's (1998) Waitangi: Morality and Reality (reviewed elsewhere in the present issue of Agenda).

5 In a personal communication dated 19 March 1998, Mr Moore indicated that he favours a written constitution.
} 
Of course, different sorts of written constitutions afford the judiciary differing degrees of power. At one end of the spectrum is the Australian-style written constitution without a Bill of Rights. This sort of straight federal model divides powers between the Commonwealth and the States, and leaves the judges as umpires of that division. The pre-1982 Canadian written constitution was another example of this type. At the other end of the spectrum are written constitutions which also entrench, and make into supreme law, some fairly general, amorphous set of moral entitlements: that is, a Bill of Rights. This sort of written constitution, most clearly exemplified by the US or by the post-1982 Canadian constitutions, proclaims as pre-eminent certain values and rights such as free speech, equality, due process, freedom of religion and so on and so forth. It then leaves it to the judges to declare what they mean in particular cases.

The former sort of written constitution clearly gives unelected judges a good deal less power than the latter. For one thing, while the Australian-style written constitution leaves the unelected judiciary free to strike down laws passed by an elected legislature, the ground for doing so is pretty well restricted to a decision that the power exercised properly lay with another elected legislature (say, the Commonwealth parliament) rather than the one trying to use it (say, the Tasmanian State Assembly). By contrast, under a US-style written constitution the unelected judges can strike down any law passed by any elected legislature if the judges believe the impugned law contravenes one of the moral rights and values set out in the entrenched Bill of Rights. The difference, then, is that in the former sort of written constitution final power over each area of basic social policy still overwhelmingly rests with one level or other of elected legislature, with the judges deciding which one, based on the words in the constitution; whereas in the latter sort of written constitution final power over large areas of basic social policy rests with unelected judges constrained only by each one's interpretation of the proclaimed rights and values. In the latter sort, unlike the former, judges are requircd to find the moral answer, not to defer to elected legislators at one level or the other.

However, even if we take it as true that an Australian-style written constitution constrains judges more than other sorts of written constitutions, it is still likely that

\footnotetext{
${ }^{6}$ For example, it is left to judges to tell us what these broadly declared rights and values mean as regards the permissibility of abortion (see Roev Wade 410 US 113 (1973)), the speed required to bring defendants to trial (see $R v$ Askov (1990) 74 DLR (4th) 355), the allowable religious elements in statefunded schools (see, inter alia, Abington School District v Schemp 374 US 203 (1963) and Wallace v Jaffree 472 US 38 (1985)), the handling of refugees (see Singh v Minister for Employment and Immigration [1985] 1 SCR 177), capital punishment (see Maymard v Cartwright 486 US 356 (1988)), and so on.

${ }^{7}$ The empirical evidence of the extent to which judges operating under a US-style or post-1982 Canadian-style written constitution have more say on fundamental social and moral issues than do their Australian counterparts is overwhelming. To give but one of many examples, could judges in Australia today have got away with striking down federal legislation which severely restricted tobacco advertising, as did the Canadian Supreme Court recently, on the ground that it impinged on commercial free speech? (See RJR MacDonald Inc. v Canada (1995) 127 DLR 1.)
} 
Australian judges have more power than they would were there no written constitution at all. In a New Zealand or UK-type constitutional structure, the fundamental or ultimate source of power is the elected parliament. Any clearly worded legislative enactment, properly passed, must be enforced by the courts whether the unelected judges like its substantive content or not. That is why the doctrine of 'parliamentary supremacy' or 'parliamentary sovercignty' is said to lie ${ }_{8}$ at the heart of the New Zealand and United Kingdom constitutional structures. Under this doctrine unelected judges must always, in the end, defer to elected legislators.

I think such deference a good thing, though admittedly this has become a minority view amongst human rights and even constitutional lawyers. On matters of basic social policy, such as abortion, immigration, and capital punishment, I favour 'letting the numbers count' - which they more or less do in New Zealand today.

By contrast, the Australian High Court in 1994 decided that, although not explicitly stated anywhere, there was an implicit guarantee in the constitution of political free speech. ${ }^{9}$ With no written constitution with which to work, their New Zealand counterparts would have found it much more difficult to create fundamental doctrines amounting to higher law. More importantly, any decision the courts do make in New Zealand can always be overridden by an Act of parliament, however politically difficult it may be for the legislature to do so. But in Australia, it would be necessary to amend the constitution in order to overturn a decision of the High Court purporting to set out what that document (explicitly or implicitly) commands. In this sense, systems without a written constitution have greater democratic credentials. $^{10}$

\section{A Constitution by Any Other Name?}

The absence of an authoritative constitutional document, entrenching some set of laws as fundamental, means that New Zealand lacks a written constitution in the formal, technical sense. But it does not mean that written documents play no role

\footnotetext{
${ }^{8}$ This is much less true of the UK since it entered the European Union. European law now is taken by the judges as trumping domestic legislation, at least up to the point where the UK parliament decided to pass legislation to leave the EU. In that case it remains still overwhelmingly likely, in my view, that the British judges would give effect to the domestic law, whatever the EU law said. To that enervated extent, the UK still enjoys parliamentary sovereignty.

${ }^{9}$ See Theophanous $v$ Herald and Weekly Times (1994) 182 CLR 104. This particular view of what the judges think they can infer from the Australian constitution has since been watered down in Lange v Australian Broadcasting Corporation (1997) 145 ALR 96.

${ }^{10}$

I make this point in much greater detail in Allan (1996) and Allan (1998). See also Minogue (1998). The fear of unclected and unaccountable judges becoming overly powerful is magnified at present in New Zealand because of the current trend towards judicial activism; see Allan (1997). The recent case of Aoraki v McGavin (CA 2/97, May 15, 1998) may or may not signal that the high tide of judicial activism has passed. In Aoraki the New Zealand Court of Appeal by a 7-0 decision overruled its own earlier case of Brighouse Ltd $v$ Bilderbeck [1994] 2 ERNZ 243 (CA) which had judicially created a right to redundancy payments.
} 
in the New Zealand constitution. Indeed, many written documents exist dealing with how, and by whom, power is exercised in New Zealand. Almost all of them are Acts of the New Zealand parliament. As such they can be repealed by a simple majority vote of the legislature (with one exception, discussed below), and so have no higher, or entrenched, or fundamental status. No past generation of New Zealanders has locked in any set of legal rules with some special or unusually difficult procedure. Each generation's parliament is supreme and is assumed to be as wise (or unwise) as its predecessors.

That said, there is a series of Acts of the New Zealand parliament that, though ordinary statutes and not entrenched against later amendment or repeal, lie at the heart of the New Zealand structure of government and allocation of powers (and hence lie at the heart of the constitution understood in a broad sense). Here, I draw attention to the most important.

First, the Constitution Act 1986 is declaratory of New Zealand's existing laws and institutions, including the sovereign, executive, legislature, summoning and dissolving of parliament, protection of judges against removal from office, and various other miscellaneous provisions. It is an ordinary statute and can be altered in the ordinary way.

Second, the Bill of Rights Act 1990 is a statutory bill of rights which sets out (in aspirational and relatively unlimited terms) the place of the individual citizen vis-àvis state power. Hence various rights and freedoms are proclaimed such as electoral rights, the right not to be deprived of life, freedom of religion, freedom of expression, freedom of movement, the right to be secure against unreasonable search and seizure, and a host of others. Again, this Bill of Rights has the status of an ordinary Act of parliament, open to repeal by simple majority vote in parliament. Indeed it is arguably of a lesser status because to secure its passage in 1990 the then government was forced to include a section which states that all other statutes (whether passed before it or after it) would prevail against the Bill of Rights Act 1990 in case of inconsistency or conflict.

Third, the Reserve Bank of New Zealand Act 1989 establishes this bank as the central bank of New Zealand and lays down that its primary function is 'to formulate and implement monetary policy directed to the economic objective of achieving and maintaining stability in the general level of prices' (s.8). Policy targets are fixed by the minister (currently 0-3 per cent inflation) but it is the duty of the Governor of the Bank to implement monetary policies consistent with the policy targets. Again, this is an ordinary statute and can be altered in the ordinary way.

Fourth, the Fiscal Responsibility Act 1994 requires the Minister of Finance to report regularly to the House of Representatives on the extent to which the government's fiscal policy is consistent with specified principles of responsible fiscal management (including reducing Crown debt to prudent levels and then maintaining these levels) and to justify any departures. Each year a budget policy statement, a fiscal strategy report and an economic and fiscal update are mandated. Perhaps more noteworthy still, an economic and fiscal update must be published by the gov- 
ernment before the holding of an election. Alteration of any of these statutory requirements is effected in the ordinary way.

Fifth, the Electoral Act 1993 comes as close as anything in New Zealand to entrenching certain legal rules so that change requires more than a simple majority in parliament. Section 268 of the Act reserves six particular provisions (dealing with the three-year maximum term of parliament, the qualifications of voters, the Commission drawing up the constituencies and its method for doing so, and the method of voting) and requires that any changes to them need either a 75 per cent vote in the House or passage in a referendum. On the face of it this sort of 'procedural entrenchment' appears to give these six provisions a higher, indeed entrenched, status. However, that appearance is misleading and the entrenchment is of moral force only. This is because s.268 of the Electoral Act 1993 has not itself been entrenched (and this omission was deliberate). Thus, any government intent on doing so need only, first, repeal s. 268 by simple majority vote and then move on to any of the six reserved provisions and amend them too, also by simple majority vote."

Finally, there is the Treaty of Waitangi, which is not an Act of the parliament of New Zealand but a short three-clause treaty signed in 1840 by various chiefs of the Confederation of the United Tribes of New Zealand and by the then LieutenantGovernor on behalf of the British Crown. In essence, the first clause cedes sovereignty to the Queen of England; the second guarantees Maori full exclusive and undisturbed possession of their lands and estates, forests, fisheries and other properties so long as it is their wish to retain them; and the third extends to them all the rights and privileges of British subjects.

The Treaty was long considered a legal nullity. Its status under international law is uncertain at best. The orthodox view is that it has no justiciable status in the municipal law unless specifically made part of an enacted statute. That said, the last two or three decades have seen the Treaty accorded an ever increasing importance. It remains the case that the courts will impose 'Treaty obligations' only where statutes specifically refer to the Treaty or to 'principles of the Treaty'. Hence it is still true today that the Treaty of Waitangi is not itself a source of law in New Zealand. Whether that will remain the case, or whether the judges in New Zealand will in the near future go on to declare that the Treaty has some higher, founding status (and thereby, in effect, change the New Zealand constitution and herald a revolution), remains to be seen. But it is certainly a possibility given the existing trend of judicial activism in New Zealand.

Does it follow from our review of these Acts and of the Treaty that New Zealand has a quasi-written constitution? That question turns so much on semantics, and on what one means by 'written', that debate about it would be sterile. The im-

\footnotetext{
"This 'single procedural entrenchment' procedure was chosen to keep parliamentary supremacy in place but also to place a moral (and in all likelihood political) bar in the way of amendment of these provisions in the usual manner.

${ }^{12}$ For a good summary of the Treaty's place in New Zealand law in all these regards, see Joseph (1993:36-78).
} 
portant point is that at present parliamentary supremacy lies at the heart of the New Zealand constitution. ${ }^{13}$ Many of the actual constitutional rules are in the form of written statutes, but ultimately no law is of a higher status and immune from change or repeal by parliamentary vote.

\section{Conclusion}

New Zealand remains a country without a written constitution. The proposed Bill by former Prime Minister Mike Moore, which would lead to a Constitutional Convention which in turn would consider the adoption of a written constitution, has little chance of enactment. In the foreseeable future at least, New Zealand is unlikely to hold a citizen- or legislature-initiated referendum on a written constitution. It is less clear, on the other hand, whether the judiciary will impose one in the form of a recognition by them of the Treaty of Waitangi as some sort of fundamental law.

My own hope is that neither eventuates. The judiciary in New Zealand is already too powerful and prone to ignore democratically elected legislators in matters of social policy-making. Constitutional entrenchment of a vaguely worded, threeclause treaty signed 150 years ago, or of the sort of written document being mooted by a few politicians, would only accentuate that trend.

\section{References}

Allan, J. (1996), 'Bills of Rights and Judicial Power - A Liberal's Quandary', Oxford Journal of Legal Studies 16: 337-52.

- (1997), 'The Rise of Judicial Activism in New Zealand', Agenda 4: 465-74.

- (1998), A Sceptical Theory of Morality and Law, Peter Lang, New York.

Joseph, P. (1993), Constitutional and Administrative Law in New Zealand, Law Book Company, Sydney.

Minogue, K. (1998), Waitangi: Morality and Reality, New Zealand Business Roundtable, Wellington.

Palmer, G. \& M. (1997), Bridled Power (3rd ed.), Oxford University Press, Auckland.

\footnotetext{
${ }^{13}$ Parliamentary supremacy is a common law doctrine that depends on no constitutive document to establish its validity.
} 